\title{
The Problem of Development of Farm Enterprises in the Krasnodar Region
}

\author{
M.V. Zelinskaya \\ E.V. Plotnikova
}

M.V. Zayceva

T.I. Chueva

\section{M.S. Osmolovskaya}

Kuban state agrarian University; Email: zelinskaya@inbox.ru

\author{
Doi:10.5901/mjss.2015.v6n5s3p164
}

\begin{abstract}
The article examines the main economic indicators of the functioning of the farm enterprises of the Krasnodar Territory and assessment of the existing measures of state support of farmers of this region. Special attention is paid to the analysis of effectiveness used of program-target method of state regulation of agriculture. The author identifies the main problems of the state regulation of farm enterprises in the Krasnodar Territory: the difficulty of obtaining loans, limited addressees product sales, difficulties in access to land resources, lack of indicators of the accounting activities of farmers. The main directions of overcoming the identified barriers to the development of farm enterprises, proposed by the author are: the organization of a new species of alternative livestock - creation on the basis of farm enterprises mini poultry farms; implementation of state management of operational accounting functions; the extension of applied indicators of statistical reflect of the economic performance index of farm enterprises for more efficient and versatile performance evaluation of their work and the timely adjustment of existing measures of state support for farmers.
\end{abstract}

Keywords: words: family farm, peasant agriculture, Krasnodar Territory, state regulation, target programs.

\section{Introduction}

The experience of successful agricultural countries confirms: family farm, peasant agriculture are the basis of sustainable development of agricultural production and a reliable food supply, the well-being of rural areas. Therefore, the issues of ensuring of conditions for effective operation and development of the main directions of state support of farm enterprises in the regions of Russia are extremely up-to-date.

According to the Civil Code of the Russian Federation peasant (farmer) enterprise is a type of self-employment in agricultural production without formation of legal entity (the state Bodies of the Russian Federation, 1994). Today it has actually become an equal member of the economic system and, consequently, an important object of state regulation (Bogoviz A.L., 2014 \& Novikov, et al., 2015). Guided by the Civil Code of the Russian Federation, the author identifies the following principles for the establishment of farm enterprises: voluntary in creating management and full freedom of choice of partners; the right of choice of the farmer is the most convenient option of obtaining the land: ownership, lifetime inheritable possession, rent, versatility, versatility of farmer; full economic responsibility for the results of their economic activity.

The main normative act regulating the rules of the functioning of farm enterprises in Russia is the Federal law "On peasant (farmer) enterprise", adopted in 2003 (the state Bodies of the Russian Federation, 2003). It defines such enterprises as a union of citizens bound by a relationship having a common property, and jointly engaged in production and other economic activities based on their personal involvement. Thus, one of the key features of the farm enterprise is the association of collective individuals.

The family farm is the centuries-old economic, social, civil, cultural and moral basic element of efficient agriculture. The creation of family farms was a central element of the reforms of P. A. (Vdovin A.I. \& Vdovin S.A., 2004 \& Karepova, et al., 2015). The basis of the family farm mortgaged the age-old desire of the farmer to be a master of his land, to be the head of a working family, to have employment income. The inclusion of all farm families in their own production, its interest in its efficiency create a healthy social and psychological climate. This explains not only economic efficiency, but 
also the social importance of this type of managing.

\section{Main Text}

In the present economic environment of the Russian Federation one of the fastest growing regions is the Krasnodar Territory (Zelinskaya M. V. \& Boltava A. L., 2014 \& Zelinskaya, et al., 2015). Its economy is widely diversified: in the structure of gross regional product significant are agro-industrial, transport, energy and recreational complexes. Also in the region quite developed is small business and in the agricultural sector are actively operating the farm enterprises (Zelinskaya M.V. \& Varava A.V., 2015).

The farming sector is the most promising in the agribusiness in the region. To this fact contribute the following circumstances: it belongs to a small business and is quite dynamic; it is characterized by high socio-economic motivation of farmers to work on ground and their full economic and legal responsibility for the results of their activities; farmers are completely independent in providing production resources and can freely exercise their entrepreneurial skills (Kundius V.A., 2010).

Product sales of farm enterprises in the Krasnodar territory and their share in all categories of enterprises are presented in table 1.

Table 1 - Key performance indexes of farm enterprises of Krasnodar Territory in 2011-2013

\begin{tabular}{|l|c|c|c|c|}
\hline Index & 2011 & 2012 & 2013 & 2013 to $2011, \%$ \\
The number of farm enterprises, units & 18005,0 & 17793,0 & 14126,0 & 78,4 \\
Sales volum - total, mln rubles & 33764,0 & 34765,0 & 39500,0 & 116,9 \\
Including products: & 31815,0 & 32771,0 & 37238,0 & 117,0 \\
- of plant growing & 1949,0 & 1994,0 & 2262,0 & 116,0 \\
- of stock-raising & 14,0 & 15,0 & 15,0 & - \\
The volume of realized by farm enterprises products from the & 20,0 & 20,0 & 20,0 & - \\
enterprises of all categories, \%: & 2,0 & 2,0 & 3,0 & - \\
- of plant growing & 908861,0 & 940083,0 & 1002364,0 & 110,3 \\
- of stock-raising & 25,1 & 26,1 & 27,4 & - \\
Cultivated area of farm enterprises, ha & & & \\
The volume of cultivated area of farm enterprises from the & & & \\
enterprises of all categories, \% & &
\end{tabular}

Thus, based on the data of table 1, the author notes the fact that farm enterprises of the region implement $15 \%$ of the production from the agricultural sector, while for the three analyzed years there is growth in sales of $17 \%$. Alarming is that the number of farm enterprises in the province during the study period decreased by $22 \%$. This trend is associated mainly with the increase of the tax burden and economic crisis in the country: as a result of these factors became the most vulnerable turned to be the category of land-poor farmer enterprises with land area of 50 hectares. However, the favorable trend according to the data in table 1 is the annual increase in cultivated areas of farm enterprises of Krasnodar Territory.

Let us dwell on the structure of the cultivated areas of farm enterprises in the region. The overall growth in cultivated areas in the region is observed owing to a substantial increase in cultivated areas of grain and leguminous crops, and vineyards (18.5\% and $56.4 \%$ respectively). Simultaneously, on most commercial crops are taken place reduction of cultivated areas: potatoes and melons at $17.3 \%$, forage crops $3 \%$, fruit and berry plantations by $6 \%$.

In farms of the Krasnodar Territory is steadily increasing grain production. Today, farmers in the region produce one fourth of the total Russian harvest. One third of the sunflower in the country is farmer's (government Bodies of Krasnodar, 2015). Realization by farmers of the main types of plant growing production in volume terms is presented in table 2. 
Table 2 - sales of the main types of plant growing products of farm enterprises in Krasnodar Territory, thousand $t$

\begin{tabular}{|l|c|c|c|c|}
\hline Index & 2011 & 2012 & 2013 & 2013 to $2011, \%$ \\
Grain of cereals and legumen crops & 2337,0 & 1952,0 & 2949,0 & 126,2 \\
Including corn & 1449,0 & 972,0 & 1633,0 & 112,7 \\
Maize & 603,9 & 740,1 & 1022,5 & 169,3 \\
Sunflowers seeds & 268,0 & 269,0 & 277,0 & 103,3 \\
Rice & 52,6 & 53,9 & 37,5 & 71,3 \\
Barley & 209,0 & 161,2 & 227,2 & 108,7 \\
Oil-bearing-crop & 317,2 & 320,2 & 332,4 & 104,8 \\
Soybeans & 43,9 & 48,2 & 45,5 & 103,6 \\
Sugar-beet (factorial) & 938,8 & 817,1 & 588,6 & 62,7 \\
Cucurbits crops (watermelons and melons) & 41,3 & 52,1 & 54,1 & 131,0 \\
Potato & 24,0 & 29,0 & 21,0 & 87,5 \\
Vegetables & 84,0 & 85,0 & 63,0 & 75,0 \\
Fruits, berries and nuts & 4,0 & 6,0 & 6,0 & 150,0 \\
\hline
\end{tabular}

Table 2 shows that for the analyzed period there is a growth in the sale of most kinds of products: sales of grain cereals and legumes increased by $26.2 \%$, corn - by $12.7 \%$, maize $-69,3 \%$, barley - by $8.7 \%$, sunflower - by $3.3 \%$, fruits, nuts and berries $-50 \%$, melons -by $31 \%$. But the sales of rice, vegetables and potatoes decreased by $28.7 \%, 25 \%$ and $12.5 \%$, respectively, due to dry weather in 2013.

Farming is the only sector of agriculture of Krasnodar Territory, where steadily grows the number of cattle stock (CS), increases milk production. Only in 2012 compared to 2011 CS on farm enterprises increased by 8\%, cows - 14\% (government Bodies of Krasnodar, 2015). Lets consider the dynamics of pattern of cattle stock in peasant farm enterprises of Krasnodar Territory in table 3.

Table 3 - Cattle stock and poultry stock by categories of farm enterprises in the Krasnodar Territory, in animal units

\begin{tabular}{|l|c|c|c|c|}
\hline Index & 2011 & 2012 & 2013 & 2013 to $2011, \%$ \\
\hline Cattle & 35646 & 36647 & 38737 & 108,7 \\
\hline Including cows & 12906 & 13953 & 14743 & 114,2 \\
\hline Pigs & 35859 & 17206 & 9412 & 26,2 \\
\hline Flocks and herds & 27476 & 28586 & 32387 & 117,9 \\
\hline Flocks & 26235 & 26885 & 31288 & 119,2 \\
\hline Goats & 1241 & 1701 & 1099 & 88,5 \\
\hline Horses & 2367 & 2714 & 2721 & 114,9 \\
\hline Rabbits & 4288 & 4295 & 5546 & 129,3 \\
\hline Nutria of cage breeding & 2997 & 2996 & 2520 & 84,1 \\
\hline Honey-bee colony, piece & 3368 & 3347 & 2915 & 86,5 \\
\hline Camels & 5 & - & 11 & 220,0 \\
\hline Donkeys & 5 & 6 & 37 & 740,0 \\
\hline Bird & 349392 & 551944 & 567020 & 162,3 \\
\hline
\end{tabular}

Table 3 shows that during the study period the stock of cattle, cows, sheep and goats, horses have increased on average by $13 \%$, also increased the number of camels by almost 2 times, donkeys - in 7 times, birds $-62.3 \%$. Thus, we see that in the livestock sector in General there is a positive trend, with the exception of pigs (this is due to the epidemic of African swine fever), and the number of goats and nutria (this is due to the unpopularity of the consumers of this product).

Next, we will consider the indexes of production of major livestock products on farm enterprises of the Krasnodar Territory in volume terms in table 4. 
Table 4 - Production of main livestock products by farm enterprises in the Krasnodar Territory

\begin{tabular}{|l|c|c|c|c|}
\hline Index & 2011 & 2012 & 2013 & 2013 to 2011, \% \\
\hline Cattle and poultry (in dead weight)- in total, t & 6995 & 6807 & 5357 & 76,6 \\
\hline including: & & & & \\
\hline - horned cattle & 1046 & 1080 & 1092 & 104,4 \\
\hline - pigs & 3872 & 3599 & 1897 & 49,0 \\
\hline - sheep and goats & 94 & 102 & 108 & 114,9 \\
\hline - bird & 1934 & 1977 & 2209 & 114,2 \\
\hline Milk, t & 68472 & 74014 & 80545 & 117,6 \\
\hline Eggs, piece & 18257 & 18277 & 18115 & 99,2 \\
\hline Wool (in gross weight), t & 55 & 56 & 53 & 96,3 \\
\hline Honey, t & 97 & 95 & 94 & 96,9 \\
\hline
\end{tabular}

Based on the data of table 4, we can conclude that the largest growth is observed in the production of milk. So in 2013 compared with 2011 production of milk increased by 12 thousand tons, while the production of wool, honey and eggs decreased slightly in the range of $1-3 \%$. The increase in milk production is due to the increase in livestock numbers and the use of modern technology.

General matters of state regulation of farm enterprises in the Krasnodar Territory are regulated by such bodies as the Legislature and the administration of Krasnodar Territory (state Bodies Krasnodar, 2015). Actual regulation is carried out by a special structural subdivision of administration - Ministry of agriculture and processing industry of Krasnodar Territory. It is the executive body responsible for the development and implementation of the state agrarian policy, and empowered by government support and implementation of state policy in the sphere of agricultural production and processing industry (Zelinskaya M.V., 2014 \& Zelinskaya M.V., 2015). That is, this Ministry is implementing the state agricultural policy in the Krasnodar Territory, aimed at creating conditions for sustainable development of agricultural production and of rural areas, increasing agricultural production, improving the efficiency of agriculture, the attainment of full employment of the rural population and increase the level of his life, rational use of land.

In the structure of the Ministry directly to questions of farm enterprises prosecute the Management of rural development and Department of development of small forms of managing and agri-tourism. These bodies implement measures of state support to farmers in the five regional target programs "Development of small forms of managing in agrarian and industrial complex on the Krasnodar Territory", "Support of beginning farmers in the Krasnodar Territory", "Pastures for grazing cows kept in subsidiary small-holdings (PSH) on the Krasnodar Territory", "The development of agriculture and regulation of markets, the Organization of rural households in small rural settlements of the Krasnodar Territory for 2013-2015". Main activities and objectives of these programs are listed in table 5 (state Bodies Krasnodar, 2015).

Table 5 - The regional target programs aimed at the development of farming

\begin{tabular}{|l|l}
$\begin{array}{l}\text { Name of the program } \\
\text { The development of small forms } \\
\text { of farming in agriculture in the } \\
\text { Krasnodar Territory }\end{array}$ & $\begin{array}{l}\text { Aims of the program } \\
\text { The formation of the economic base for sustainable } \\
\text { development of rural areas, competitive small farm } \\
\text { enterprises (SFE), the improvement of the material situation } \\
\text { of the inhabitants of rural areas, increasing employment } \\
\text { and living standards of the rural population }\end{array}$ \\
& \\
$\begin{array}{l}\text { Support beginning farmers in the } \\
\text { Krasnodar Territory for 2012- } \\
2014\end{array}$ & $\begin{array}{l}\text { Encouraging of the creation of in the region of farm } \\
\text { enterprises }\end{array}$ \\
Pastures for grazing cows kept & The implementation of complex organizational, economic, \\
\end{tabular}

\begin{tabular}{|l|} 
The activities of the program \\
Organizational provisions of development of SFE and \\
agribusiness \\
The effective organization of production of competitive \\
agricultural products in the SFE and agribusiness \\
The organization of the system of sales, \\
transportation, storage and processing of products \\
produced in the SFE and agribusiness \\
Information and advice service \\
The organizational system of accounting of production \\
and marketing of agricultural products \\
Development of a system of agricultural consumer \\
cooperation in Krasnodar Territory \\
Organization and participation in exhibition activities \\
The creation of family livestock farms \\
Grants for the creation and development of farm \\
enterprises \\
Providing one-time assistance for domestic \\
arrangements \\
Conducting training seminars for beginning farmers \\
Provision of land for the establishment of cultivated
\end{tabular}




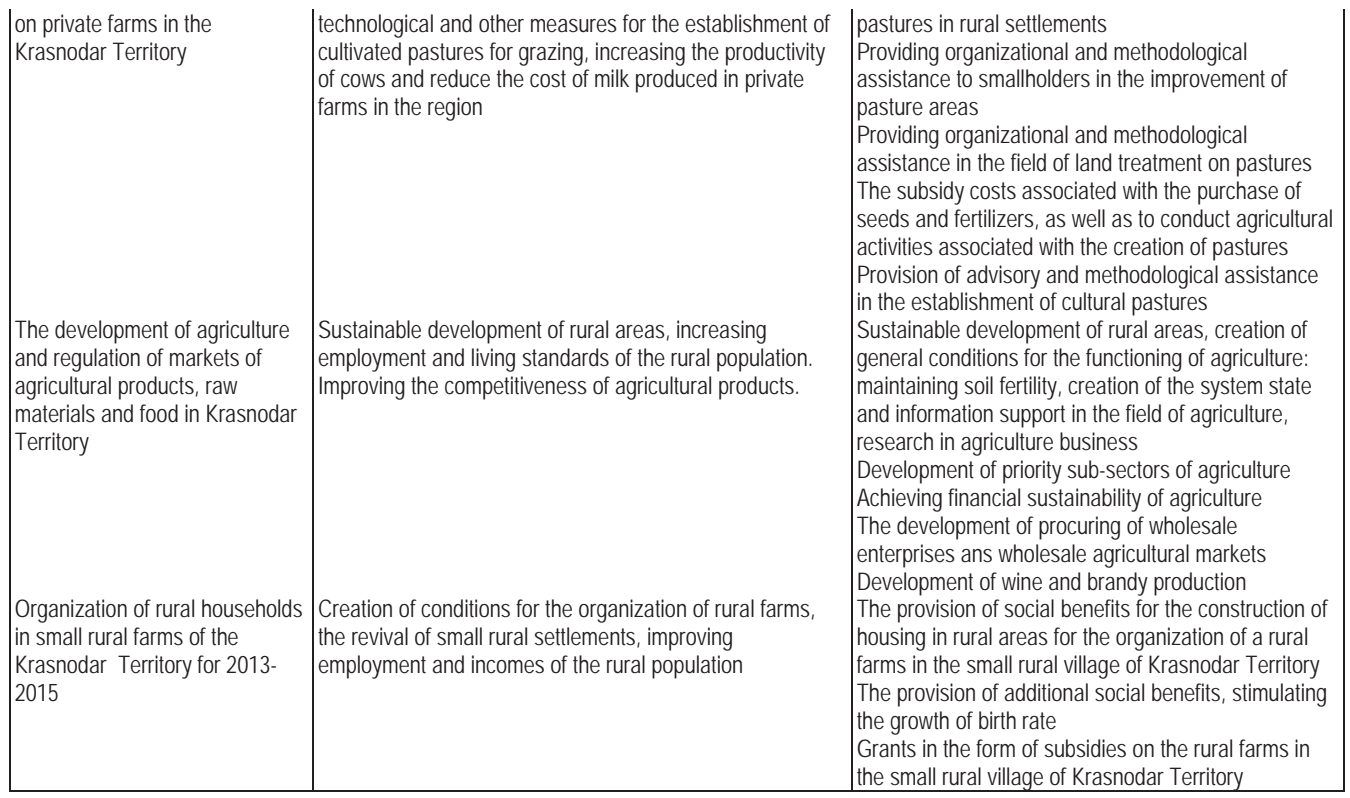

Activities of the regional target program "Development of agriculture and regulation of markets of agricultural products, raw materials and food in Krasnodar Territory" include providing farmers with financial support, coaching the cadres of the agro-industrial complex, the conservation of soil fertility in the Krasnodar Territory, as well as raising the living standards of the rural population of the region. Funding levels for this program are presented in table 6.

Table 6 - Activities of the regional target program "Development of agriculture and regulation of markets of agricultural products, raw materials and food in Krasnodar Territory" and the volume of financing from the regional budget, thousand rubles

\begin{tabular}{|c|c|c|c|}
\hline Activities & 2011 & 2012 & 2013 \\
\hline $\begin{array}{l}\text { Increasing the level of social infrastructure development and engineering construction of rural } \\
\text { settlements }\end{array}$ & 273284,1 & 255284,1 & - \\
\hline The maintenance of soil fertility & 165496,4 & 99097,1 & - \\
\hline Creation of system of the state information support in the sphere of agriculture & 10000,0 & 8000,0 & - \\
\hline $\begin{array}{l}\text { Development consulting assistance to agricultural producers and retraining of specialists for } \\
\text { agriculture }\end{array}$ & 48200,0 & 21800,0 & - \\
\hline Research priorities in agriculture & 6000,0 & 6000,0 & - \\
\hline $\begin{array}{l}\text { Compensation of part of expenses of subjects of small business on training and practical training of } \\
\text { students of higher professional education in areas of "Fruit and vegetables rowing" and "Viticulture" } \\
\text { on the material-technical base of small businesses in agriculture }\end{array}$ & 300,0 & - & - \\
\hline $\begin{array}{l}\text { Organization of events to promote agricultural products produced in the SFE on domestic and foreign } \\
\text { markets (participation in festivals, exhibitions, fairs, competitions with bonuses) }\end{array}$ & & 800,0 & - \\
\hline Priority livestock development & 53966,7 & 63454,9 & - \\
\hline The development of plant industry & 222733,3 & 227220,0 & - \\
\hline Support the development of frame area vegetable production & - & 30000,0 & - \\
\hline Support of dairy cattle breeding & - & 50000,0 & - \\
\hline The development of agricultural land reclamation & - & 40000,0 & - \\
\hline The elimination and prevention of the spread of African swine fever in Krasnodar Territory & - & 20000,0 & - \\
\hline Increasing the availability of loans & 314459,7 & 405078,3 & - \\
\hline Improvement of financial viability of small rural businesses & 8886,6 & 5500,0 & - \\
\hline of insurance of risks in agriculture & 81281,6 & 26212,8 & - \\
\hline Actions for the development and procurement of wholesalers and wholesale agricultural markets & - & 4074,8 & - \\
\hline The development of the wine and brandy production & 125677,0 & 15200,0 & - \\
\hline Grants in the form of subsidies on the rural farms in the sma & - & & 30000,0 \\
\hline
\end{tabular}


Every year in the region was held the event "Kuban fair" during which farmers have the opportunity to implement and advertise their products (Kobersy, et al., 2015), as well as participate in competitions in the areas of livestock and crop production.

At realization of the program "Support to beginning farmers for 2012-2014" following was done:

1 Granting to farmers and entrepreneurs of subsidies for reimbursement of expenses associated with the establishment, expansion and modernization of production base. The subsidy is of up to 1.5 million rubles (see table 7).

Table 7 - Subsidies for the establishment, expansion and modernization of production base, thousand ruble

\begin{tabular}{|l|c|c|c|c|}
\hline Index & 2012 & 2013 & 2014 & 2014 to 2012, \% \\
The number of beginning farmers who received subsidies (target indicator) & 25 & 75 & 75 & 300,0 \\
Subsidies - total & 38200 & 111700 & 111700 & 292,0 \\
Including federal budget & 28650 & 83775 & 83775 & 292,0 \\
From regional budget & 9550 & 27925 & 27925 & 292,0 \\
\hline
\end{tabular}

2 The subsidization of the costs incurred during the construction or acquisition of housing, landscaping and residential housing arrangement by farmers and entrepreneurs. The subsidy is to 250 thousand rubles (see table 8).

Table 8 - Subsidies for reimbursement of the costs incurred in the construction, improvement and acquisition of housing, thousand rubles

\begin{tabular}{|l|c|c|c|c|}
\hline Index & 2012 & 2013 & 2014 & 2014 To 2012, \% (times) \\
The number of beginning farmers who received subsidies (target indicator) & 5 & 75 & 75 & в 15 pa3 \\
Subsidies - total & 1250 & 18750 & 18750 & в 15 ра3 \\
Including federal budget & 1000 & 15000 & 15000 & в 15 ра3 \\
From regional budget & 250 & 3750 & 3750 & B 15 ра3 \\
\hline
\end{tabular}

3 Subsidizing the costs associated with payment of the initial payment at the acquisition in leasing of agricultural machinery, equipment and livestock. The subsidy is not more than $1 / 15$ of the value of the leased asset (50/50) - see table 9.

Table 9 - Subsidies for purchase of agricultural machinery, equipment and livestock, thousand rubles

\begin{tabular}{|l|c|c|c|c|}
\hline Index & 2012 & 2013 & 2014 & In total for 2012-2014 \\
\hline The cost of machinery, equipment and livestock, leased by beginning farmers & - & 454545 & 454545 & 909091 \\
\hline Subsidies - total & - & 30000 & 30000 & 60000 \\
\hline Including federal budget & - & 15000 & 15000 & 30000 \\
\hline From regional budget & - & 15000 & 15000 & 30000 \\
\hline
\end{tabular}

4 There is an annual competition "The best beginning farmer". The purpose of the event is the lighting of the positive experience of creating new farms and assessing their success. Funding for the competition "The best beginning farmer" and the preparation of informational materials for beginning farmers are presented in table 10.

Table 10 - Costs of holding the competition "The best beginning farmer", thousand rubles

\begin{tabular}{|l|c|c|c|c|}
\hline Index & 2012 & 2013 & 2014 & 2014 to 2012, \% \\
\hline A number of competitions & 1 & 1 & 1 & 100,0 \\
\hline The costs of 1 competition & 150 & 150 & 150 & 100,0 \\
\hline The costs of publication of informational materials, brochures & 50 & 50 & 50 & 100,0 \\
\hline
\end{tabular}

Thus, public authorities in the Krasnodar Territory pay considerable attention to the development of farm enterprises, here takes place the work which is currently focused on the development of farming, raising the level of agricultural production in farm enterprises to the level of large and medium-sized agricultural enterprises, improving the efficiency of their work, also with the help of the provision of state support measures. Conducted by the author analysis of the functioning of state administration bodies in this study area allowed us to identify problems in state regulation, which is 
presented in figure 1. Let's consider the following issues and offer solutions to them. According to the author, the main problem faced by the Kuban farmer is the problem of crediting: this is unavailability of credits for small businesses, and high interest rates, and a significant time lag in obtaining grants and obligations on interest payment, and closure of additional offices of Rosselkhozbank in rural settlements and district centers. In our opinion, to solve this set of problems it is necessary to strengthen the work of the Agency of credit guarantees through the Central Bank of the Russian Federation, Sberbank of Russia, etc., as well as the Central Bank of the Russian Federation should reduce the cost of resources for commercial banks in lending to agribusiness industry.

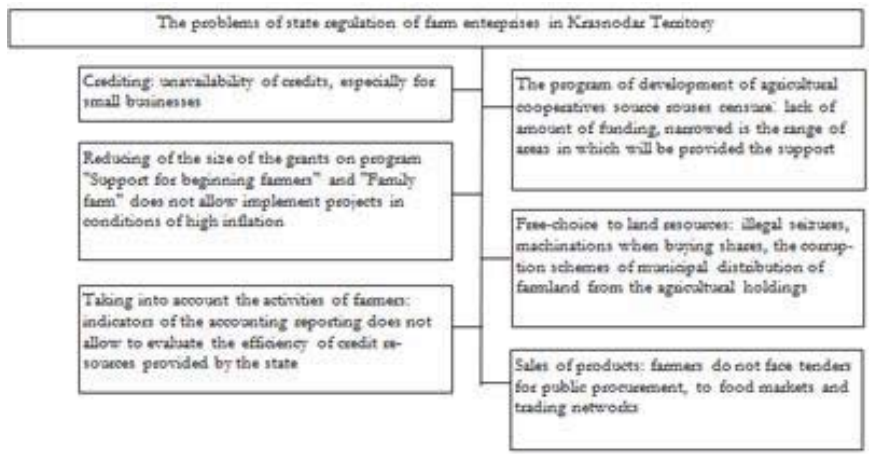

Figure 1 - Problems of state regulation of farms in the Krasnodar Territory

As a barrier to the development of farming in Kuban is the problem of access of farm enterprises in the region to land resources. The problem is caused by illegal seizures of land, machinations when buying shares, corrupt schemes of municipal distribution of farmland from the agricultural holdings. To solve this issue are encouraged to donate at least for five years of agricultural land to ownership of farmers, effectively using the land, from the land of lifetime inheritable possession and leased land from the land of redistribution fund.

The author specifically isolating the problem of the support programs of the beginning farmers and family farms, namely the lack of funds for these programs, as the number of applications of the average in RF in 7 times exceed the amount of funding, and the reduction in the size of grants does not let to implement investment projects in the conditions of high inflation. It is necessary to increase funding for these programs due to the massive interest of rural people to them.

In addition, to the problems also can be referred the existing order of implementation of the program of development of agricultural cooperation: lack of funding, narrowed range of areas in which support will be provided. It is therefore necessary to increase the amount of funds allocated to the program of development of agricultural cooperation, expand areas of support (primarily on the establishment of slaughter units).

Problem of production distribution has always been important for Russian farmers, since they do not have access to the tenders for public procurement, to food markets and trading networks. To address this problem, the author considers it necessary to amend the law on the contract system in terms of providing benefits to domestic agricultural producers in the procurement of goods (agricultural products), to introduce a system of food ordering for small business, to create wholesale and logistics centers on a cooperative basis with the increase in the share of financing from the state budget and regional legislation to provide for the creation of a municipal order, purchase food for social institutions, organizations and population of the region as a priority among agricultural producers in their region.

In our opinion, the actual problem of state regulation of activity of farms in the Krasnodar Territory is the problem of their statistics. Conducted by the author the analysis showed that, in addition to taking account of sown area, the volume of sales in natural expression, it is necessary also to keep records of sales in value terms (this will allow to assess the condition of farms in the agricultural market). Also we see the merit of the statistics not only on subsequent periodic basis at the time of the all-Russian agricultural census, but on an ongoing basis in the form of online surveys (see figure 2).

Governments should conduct outreach activities in rural settlements for the collection of operational data. The proposed indicators will allow not only to assess the economic efficiency of farms for investors, but also to quickly track the implementation of targeted programs and the implementation of the grants to farmers. This will also allow to evaluate the efficiency of credit resources and will help the farmers to assess their results in a common perspective for formation 
of strategy of development of the economy.

With due regard for measures for African swine fever liquidation and the current economic and geopolitical situation took place at the period observed the initiation of alternative livestock farming is of a great importance for the State at the present stage of economic development. Let's offer Kuban farmers such a type of livestock farmers as chicken farming, and determine the effectiveness of the mini poultry farm functioning.

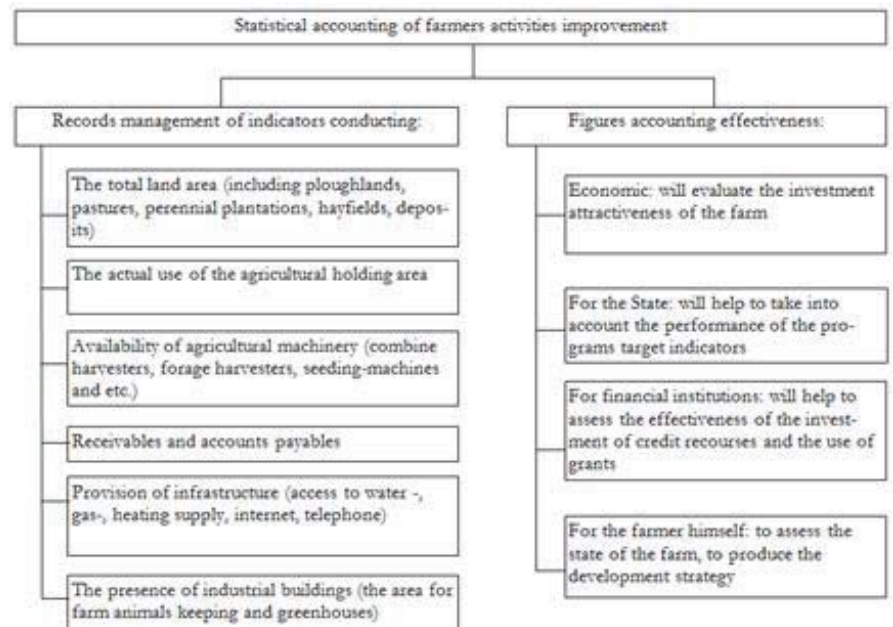

Figure 2 - Statistical accounting of farmers activities improvement in Krasnodar Territory

Poultry and eggs are among the most popular and essential food products in Russia. They have greater bioavailability for the human body. Chicken meat and eggs are dietary products having market demand. According to the Ministry of economic development in the coming years the consumption of poultry meat in Russia will only increase (L.M. Boukharaeva, M. Marloie, 2015). In recent years poultry import in our country began to decline, which means that the activity of producers on the domestic market should grow. Business associated with the process of breeding and rearing chickens is a profitable and cost-effective one. According to various sources the profitability of poultry production is reaching $60 \%$. This kind of business is close to rural residents and those who have a rural property. With the right approach, "bird business" can become virtually waste-free.

Let's consider the example of opening a mini poultry of 1,000 birds. Assume that the facilities for a mini poultry farm are already ready and there is no cost for its construction required.

As the sources of funding for the project can be:

1. Participation in the state program of support beginning farmers or family livestock farms development. The maximum support grant for beginning farmers is reaching 1,500 thousand rubles. Agricultural business is considered a priority, so the chance to get the support is great.

2. Participation in preferential credit programs. Some banks offer loans for agricultural enterprises at low interest rates $(12 \%)$.

The main costs for the purchase of equipment, poultry and the rest for the start of the project are presented in Table 11.

Table 11 - Investment outlay for a mini poultry farm establishing on the basis of a peasant farm

\begin{tabular}{|l|c|}
\hline Item of expense & Total, rubles \\
Egg chickens aged 30 days & 30000 \\
Broiler chickens aged 30 days & 55000 \\
Cages & 100000 \\
Other equipment (troughs, buckets, etc.) & 40000 \\
Facilities repair & 50000 \\
The rest & 20000 \\
Total & 295000 \\
\hline
\end{tabular}


Thus, the initial investment at the start of the project, taking into account the farmer already possessing required facilities, is 295 thousand rubles.

A mini poultry farm can operate in several areas: production of poultry meat and egg with the subsequent realization of finished products to the public; setting their own incubator for poultry (chickens) rearing.

According to the author, while creating a poultry farms in the Krasnodar region it is advisable to include the following breeds of chickens:

1. Good laying hens, "Leggorn" or egg breeds crosses. They have good ripening, the average egg production of each hen is area up to 200 eggs per year.

2. Broiler poultry, such as "Cornish", "Brahma", "Cochinchina", "Cobb 500" breeds. Live weight of adult cocks of these species is up to $5 \mathrm{~kg}$, hens - up to $3 \mathrm{~kg}$.

To keep 1000 birds the facilities from $100 \mathrm{sq} \mathrm{m}$ are required. To make more efficient use of space one should use the cage method of poultry keeping. In the case of this method using it is recommended to put 5 birds per $1 \mathrm{sq} \mathrm{m}$. To save space, the cages can be mounted in 2-3 tiers. Cages can be hand-made or purchased from the manufacturer. One cage price for 5 birds starts at 2,000 rubles or more. If a poultry farm is planned the reproduction of poultry, it is advisable to use Russian equipment - Incubator ILB-0.5M. Incubator intervene 770 eggs. The period of incubation of chickens is 2122 days.

It is expected that meat and egg breeds of chickens will be kept in equal proportions (500 birds each breed). On average broiler poultry meat reaches its dressed weight on the 50th day. Accordingly, it is possible to rear 7 generations per 1 year. In total about 3,500 birds or 10.5 tons of poultry meat per year will be reared. On average goods laying hens give 200 eggs per year. Accordingly, 500 goods laying hens will bring up to 100 thousand eggs per year.

One of the main principles of the proper poultry keeping is the maintenance of a favorable microclimate in the room. Chicks and grown chickens must be kept in separate rooms because of the difference in the desired heating and lighting mode. For example, for day-old chickens the temperature at 34 degrees is required, while for the 60-day chickens the temperature at 18 degrees is enough. In the case of cage keeping for young growth chicks in the first 3 weeks twentyfour-hour lightning is recommended. In the process of chicks growth the artificial lighting reduces up to 17 hours. To the feeding diet of chickens it is necessary to include grain, feedstuffs of vegetable and animal origin, flour mixes and also food rich in vitamins and easily digestible protein. To support all working process of a poultry farm, including poultry feeding, egg collection, the slaughter of adult birds, etc. one must hire a minimum of three workers. With a planned wage fund for each employee in 30,000 rubles per month, the annual wage fund will be 360,000 rubles.

The large poultry farms which have their own points of sale will be the main competitors to a mini poultry farm in the Krasnodar region. Typically, these companies maintain a relatively low level of prices and have already gained a base of regular customers. Therefore, we recommend the farmer to carry out the sale of its products in the following: in the format of "itinerant trade" in the places with a big number of passers-by, for example, in the markets; by supplying products to retail outlets in nearby areas; by selling products directly from the production to wholesale organizations. In an ideal economic situation one must install his own sales outlets (kiosks or pavilions), but this requires large volumes of production and absolutely different investments.

One of the undeniable competitive advantages is the fact that the product of a mini poultry farm is produced in "domestic", environmentally friendly conditions. Meat and eggs are of good quality and it is certainly a big pros for the modern consumer. Annual production plan of the mini poultry farm is presented in Table 12.

Table 12 - Annual production plan of a mini poultry farm

\begin{tabular}{|l|c|}
\hline Index & Amount planned \\
Poultry meat: & 10500 \\
- volume of sales, kg & 100 \\
- price per 1 kg, ruble & 1050 \\
- gain, thousand rubles & \\
Eggs: & 100000 \\
- volume of sales, item & 4 \\
- price per 1 item, ruble & 400 \\
- gain, thousand rubles & 1450 \\
Gain - total & \\
\hline
\end{tabular}

It is planned to sell $10500 \mathrm{~kg}$ of meat and 100000 items of eggs per year, when the total gain will be of 1,450 thousand rubles. The monthly costs of operation of the proposed mini poultry farm are presented in Table 13. 
Table 13 - Current expenditures on the operation of a mini poultry farm per month, rubles

\begin{tabular}{|l|c|}
\hline Index & Amount \\
\hline Wages & 30000 \\
\hline Feed stuff, vitamins & 10000 \\
\hline Taxes (unified agricultural tax), 6\% & 3000 \\
\hline Contributions to non-budgetary funds, 30\% & 9000 \\
\hline Utilities & 5000 \\
\hline Day-old chickens purchasing & 9000 \\
\hline The rest & 4000 \\
\hline Total & 70000 \\
\hline
\end{tabular}

Total monthly costs of a mini poultry farm account for 70 thousand rubles. The calculation of the efficiency of a family mini poultry farm set up on the basis of a peasant farm in the Krasnodar region are presented in Table 14.

Table 14 - The calculation of the efficiency of a family mini poultry farm

\begin{tabular}{|c|c|}
\hline \multirow{2}{*}{\multicolumn{2}{|c|}{$\begin{array}{l}\text { Index } \\
\text { The calculation of the investment and operating costs }\end{array}$}} \\
\hline & \\
\hline $\begin{array}{l}\text { Investment costs for the operation of a mini poultry farm - total, } t \\
\text { including: }\end{array}$ & 295 \\
\hline - facilities repair (area of 100 sq m for 1000 birds keeping) & 50 \\
\hline - egg chickens aged 30 days purchasing (500 birds) & 30 \\
\hline - broiler chickens aged 30 days purchasing (500 birds) & 55 \\
\hline - cages purchasing & 100 \\
\hline - other equipment purchasing (troughs, buckets, etc.) & 40 \\
\hline - the rest (Gossanepidnadzor certification and etc.) & 20 \\
\hline $\begin{array}{l}\text { Current expenditures on the operation of a mini poultry farm per } \\
\text { including: }\end{array}$ & 840 \\
\hline $\begin{array}{l}\text { - annual wage fund of workers needed to maintain poultry farm } 0 \\
\text { collection of eggs, etc.) }\end{array}$ & 360 \\
\hline - payments to non-budgetary funds, $30 \%$ & 108 \\
\hline - taxes (unified agricultural tax), $6 \%$ & 36 \\
\hline - feed stuff, vitamins & 120 \\
\hline - day-old chickens purchasing & 108 \\
\hline - utilities & 60 \\
\hline - other costs & 48 \\
\hline \multicolumn{2}{|c|}{$\begin{array}{l}\text { Calculation of the planned volume of finished products of a mini poultry farms for } 1000 \text { birds per year, and the annual gain from its } \\
\text { sale }\end{array}$} \\
\hline \multicolumn{2}{|c|}{ Broiler poultry } \\
\hline - dressed weight achievement on average, days & 50 \\
\hline - the amount of generations, that can be grown per year & 7 \\
\hline - the amount of birds, that can be grown per year & 3500 \\
\hline - the average weight of one broiler poultry, $\mathrm{kg}$ & 3 \\
\hline - the total weight of poultry reared for the year, $\mathrm{kg}$ & 10500 \\
\hline - the price of $1 \mathrm{~kg}$ of poultry meat, ruble & 100 \\
\hline - annual revenue from the sale of poultry, thousand rubles & 1050 \\
\hline \multicolumn{2}{|l|}{ Egg poultry: } \\
\hline - average egg production of one bird per year, items & 200 \\
\hline - total egg production of 500 laying hen per year, thousand items & 100 \\
\hline - 1 egg price, ruble & 4 \\
\hline - annual revenue from the eggs sale, thousand rubles & 400 \\
\hline \multicolumn{2}{|l|}{ Key indicators of business efficiency } \\
\hline Annual revenues of a mini poultry farm - total, thousand rubles & 1450 \\
\hline Annual gain of a mini poultry farm, thousand rubles & 610 \\
\hline The profitability of current expenses, $\%$ & 72,6 \\
\hline Payback period, months & 5,8 \\
\hline
\end{tabular}

As it is shown in the analysis represented, the current costs of the operation of a mini poultry farm per year will amount to 
840 thousand rubles, the investment costs (including the construction of facilities, the purchase of chickens, equipment and cages) will amount to 295 thousand rubles. In these expenses the gain from the sale of poultry is planned in the amount of 1050 thousand rubles, and from the sale of eggs - 400 thousand rubles. On the basis of the planned volume of finished products and annual revenue from its selling we have the following indicators of the project efficiency: the annual farmer revenue will amount to 1450 thousand rubles, the annual profit - 610 thousand rubles, cost-efficiency - $72.6 \%$. In this connection the payback period will make it of 6 months.

As we can see from the above calculations, the profitability of the project is high, the payback period is small. Consequently, the establishment of a mini poultry farm on the given business plan is economic. We believe that the overall efficiency of the implementation of such projects in the economy of Krasnodar region is caused by the positive dynamics in the development of agriculture in general, in the increase in the number of farms in the region, in the growth in the production of eggs and poultry meat, and, consequently, in the increase in tax revenues. In addition, the creation of a mini poultry farm will help to increase the number of jobs and employment in rural areas.

\section{Conclusion}

According to the author, farm enterprises in the Krasnodar Territory have great potential to increase agricultural production and food self-sufficiency, and are an integral part of the peasant way of life of the rural population. Therefore, the given subjects of the economic system of the region are very promising and in need of state regulation.

The study period from 2011 to 2013 is characterized by positive dynamics in the socio-economic development of the Krasnodar Territory. In addition the small form of management is crucial in ensuring food security of the region and the country. Farm sector is the most dynamic and promising sectors of agro industrial complex. However, during the study period the number of farms in the Krasnodar region has decreased in $21.6 \%$ due to the economic crisis, as well as to an increase in the tax burden. But at the same time the volume of products selling by farmers of the region in animal husbandry and in plant growing are increased in $17 \%$.

The Ministry of Agriculture and Process Industry regulates agriculture in the region, the department of small farming and agro-tourism development regulates farm enterprises directly. The main method of state regulation is a management by objectives one. The department carries out the state policy and regulation in the area of small farms development, takes measures for the implementation of agricultural products, consultations and meetings for farmers, promotes cooperation. The analysis held in the paper allowed to identify the main problems of activity of farms in the Kuban: the complexity of crediting, product selling, access to land, the problem of the implementation of purpose-oriented programs (program in creating cooperatives - a narrow range of areas), as well as reducing the size of grants in the context of high inflation, accounting problems of farming.

As the improvement of state regulation, the author suggests the following activities: 1) to keep statistics on indicators not only at the period of the All-Russian agricultural enumeration but on a temporary basis. At the same time to use such indicators as the total land area, the actual use of the agricultural land area, the availability of agricultural machinery (combine harvesters, forage harvesters, seeding-machines and etc.), receivables and accounts payables, provision of infrastructure (access to water -, gas-, heating supply, internet, telephone) and the presence of industrial buildings (the area for farm animals keeping and greenhouses); 2) to perform the side-off events for accounting or to oblige the structural units of local government to implement the operational accounting functions. This will help the better sovereign-state regulation in this sphere; 3 ) with due regard for the current economic and geopolitical situation the initiation of alternative livestock farming is of great importance for the region and the state. The project of creating a mini poultry farms is suggested. The developed business plan shows that the profitability of a farm operation is high, the payback period is small, therefore, the establishment of a mini poultry farms is economic.

On the whole the system of the measures proposed will help to assess the activities of farmers of Krasnodar region better, will contribute to the orderly development of farms, to the increase in jobs, will improve the investment attractiveness of the farm sector, as well as will contribute to the positive economic development of the region, since it is expected not only economic but also social effectiveness of the measures proposed.

\section{References}

Bogoviz, A.L. (2014) Features of the Formation and Direction of the Agrarian Policy of Russia // AIC: economy, management. № 5.

Vdovin, A.I. and Vdovin S.A. (2004) The History of Management of Agriculture in the County - in the district - in the Municipal union: teaching practical edition. SPb.: Publishing house "Biznes-pressa".

Zielinska, M.V and Boltava A.L. (2014) Features of the State and Regional Economy of the Krasnodar Territory // Economics and 
Entrepreneurship. Moscow. № 11 pp. 3, (52-3).

Zielinska, M.V. (2015) State Support of the Business of Krasnodar Territory // Polythematic network electronic scientific journal of the Kuban State Agrarian University (Science magazine of KubSAU) [electronic resource]. - Krasnodar KubSAU. №03 (107). IDA [article ID]: 1071503037. Access mode: http://ej.kubagro.ru/2015/03/pdf/37.pdf

Zielinska, M.V., Varava A.V. (2015) Improvement of the Organization of Management of Agriculture in the Municipal union of Krasnoarmeysky District // Polythematic network electronic scientific journal of the Kuban State Agrarian University (Science magazine of KubSAU) [electronic resource]. - Krasnodar KubSAU. №04(108). IDA [article ID]: 1081504079. Access mode: http://ej.kubagro.ru/2015/04/pdf/79.pdf

Zielinska, M.V. (2014) Customs and Tariff Regulation as an Instrument of Government Support of Agro-industrial Complex of Krasnodar Krai // Polythematic network electronic scientific journal of the Kuban State Agrarian University (Science magazine of KubSAU) [electronic resource]. - Krasnodar KubSAU. №10(104). IDA [article ID]: 1041410093. - Access mode: http://ej.kubagro.ru/2014/ 10/pdf/93.pdf

Kundius, V.A. (2010) Economics of Agroindustrial Complex: manual. M.: KNORUS.

Louiza, M. (2015) Boukharaeva, Marcel Marloie. Family Urban Agriculture in Russia. Lessons and Prospects. DOI 10.1007/978-3-31911614-3. Switzerland: Springer International Publishing.

The official website of the Ministry of Agriculture and Process Industry of Krasnodar Region. [Electronic resource]. Access mode: http://www.dsh.krasnodar.rul

The Federal Law from 30.11.1994 N 51-FL "Civil Code of the Russian Federation (Part One)" // Information - Legal Portal. http:/l base.garant.ru/

The Federal Law from 11.06.2003 N 74-FL "On the Peasant (Farmer) Economy" // Information - Legal Portal. http:// base.garant.ru/

Novikov, V.S., Klochko, E.N., Yarushkina, E.A., Zhukov, B.M. \& Dianova, V.A. (2015) On peculiarities of the virtual economy of modern Russia: categories, virtual relationships, educational constructs. Mediterranean Journal of Social Sciences, 363 (247-257).

Karepova, S.G., Karabulatova, I.S., Klemovitsky, S.V., Novikov, V.S., Stratan, D.I. \& Perova, A.E. (2015) New approaches to the development of methodology of strategic community planning. Mediterranean Journal of Social Sciences, 363 (357-363).

Zelinskaya, M.V., Mezhlumova, V.R., Boltava, A.L., Tarasova, O.Y. \& Gadzheiva, E.Y. (2015) Higher education of Krasnodar Krai: economic aspects. Mediterranean Journal of Social Sciences, 363 (225-235).

Kobersy, I., Karyagina, A., Karyagina, O., \& Shkurkin, D. (2015). Law as a Social Regulator of Advertisement and Advertising Activity in the Modern Russian Information Space. Mediterranean Journal Of Social Sciences, 6(3 S4), 9. Retrieved from http://www.mcser. org/journal/index.php/mjss/article/view/6705 